\title{
Paleocene sea-level and productivity changes at the southern Tethyan margin (El Kef, Tunisia)
}

\author{
Elisa Guasti ${ }^{\mathrm{a}, *}$, Tanja J. Kouwenhoven ${ }^{\mathrm{b}}$, Henk Brinkhuis ${ }^{\mathrm{c}}$, Robert P. Speijer ${ }^{\mathrm{d}}$ \\ ${ }^{a}$ Department of Geosciences (FB 5), Bremen University, P.O. Box 330440, 28334 Bremen, Germany \\ ${ }^{\mathrm{b}}$ Department of Earth Sciences, Utrecht University, Budapestlaan 4, 3584 CD Utrecht, The Netherlands \\ ${ }^{\mathrm{c}}$ Laboratory of Palaeobotany and Palynology, Utrecht University, Budapestlaan 4, 3584 CD Utrecht, The Netherlands \\ ${ }^{\mathrm{d} D e p a r t m e n t ~ o f ~ G e o g r a p h y ~ a n d ~ G e o l o g y, ~ K . U . ~ L e u v e n, ~ R e d i n g e n s t r a a t ~ 16, ~} 3000$ Leuven, Belgium
}

Received 24 August 2004; received in revised form 22 December 2004; accepted 3 January 2005

\begin{abstract}
Integrated analysis of quantitative distribution patterns of organic-walled dinoflagellate cysts (dinocysts) and benthic foraminifera from the Paleocene El Kef section (NW Tunisia) allows the reconstruction of sea-level and productivity fluctuations. Our records indicate that the environment evolved from an initially oligotrophic, open marine, outer neritic to upper bathyal setting towards a more eutrophic inner neritic setting, influenced by coastal upwelling by the end of the Paleocene. An overall second order change in paleodepth is reflected by both microfossil groups. From the base of planktic foraminifera Zone P4 onwards, the main phase of shallowing is evidenced by an increase of inner neritic dinocysts of the Areoligera group, disappearance of deeper-water benthic foraminifera and increasing dominance of shallow-marine taxa (several buliminids, Haplophragmoides spp., Trochammina spp.). The total magnitude of this shallowing is obscured by interaction with a signal of eutrophication, but estimated to be around $150 \mathrm{~m}$ (from $\sim 200$ to $\sim 50 \mathrm{~m}$ ). Superimposed on the overall trend, third order sea-level fluctuations have been identified and correlated to sequences in other regions. Paleoproductivity indicators (notably protoperidinioid dinocysts and buliminids) show a trend from an oligotrophic to a eutrophic setting.
\end{abstract}

(C) 2005 Elsevier B.V. All rights reserved.

Keywords: Organic-walled dinoflagellate cysts; Benthic foraminifera; Paleocene; Paleoenvironment; Sea-level; Tethys

\footnotetext{
* Corresponding author. Tel.: +49 421218 7144; fax: +49 421 2184515.

E-mail addresses: eguasti@uni-bremen.de (E. Guasti), tkouwenh@geo.uu.nl (T.J. Kouwenhoven),H.Brinkhuis@bio.uu.nl (H. Brinkhuis), $\bar{\equiv}$.speijer@geo.kuleuven.ac.be (R.P. Speijer).

0377-8398/\$ - see front matter (C) 2005 Elsevier B.V. All rights reserved. doi:10.1016/j.marmicro.2005.01.001
}

\section{Introduction}

The Paleogene has become appreciated as a climatically highly dynamic period, involving the transition from the near ice-free world of the Cretaceous to the glacially dominated world of the Neogene (Zachos et al., 2001). In this context, 